\title{
Polycaprolactone: How a Well-Known and Futuristic Polymer Has Become an Innovative Collagen-Stimulator in Esthetics
}

This article was published in the following Dove Press journal: Clinical, Cosmetic and Investigational Dermatology

\author{
Marie-Odile Christen' \\ Franco Vercesi ${ }^{2}$ \\ 'BEHAVIOR, Paris 75II6, France; \\ ${ }^{2}$ Centro Medico Galeno, Milano 20122, \\ Italy
}

\begin{abstract}
Compared to other domains, tissue engineering and esthetics have dramatically expanded in recent years, leading to both major biomedical advances and futuristic perspectives. The two share a common approach based on biomaterials, especially polymers. This paper illustrates this with the example of polycaprolactone (PCL), a polymer synthesized in the early 1930s, and one of its most recent applications, a PCL-based collagen stimulator, a filler used in esthetics. PCL is biocompatible and biodegradable. Its specific physicochemical and mechanical properties, viscoelasticity and ease of shaping led to the production of PCL-based products with various shapes and durations dependent on its biodegradation kinetics. PCL has been safely used in the biomedical field for more than 70 years, from sutures to tissue and organ replacement by $3 \mathrm{D}$ printing. The PCL-based collagen stimulator is composed of PCL microspheres suspended in a carboxymethyl-cellulose gel carrier providing immediate and sustained volumizing effects when injected; the morphology, the biocompatibility of the PCL microspheres embedded with the collagen fibers produced all contribute to the creation of a unique 3D scaffold for a sustained effect. Its safety has been investigated in clinical studies and vigilance surveys. Recently published experts' recommendations on injection modalities and techniques should help further optimize treatment outcome and safety. This paper also integrates reviews and recommendations on the prevention and management of adverse events related to dermal and subdermal fillers including the PCL-based collagen stimulator. In addition, in terms of efficacy and safety, this product benefits from its daily clinical use in esthetics worldwide and continuous extensive fundamental and clinical research, both on it and the PCL polymer. Forthcoming data from further investigations will reinforce knowledge of the product and procedures in the field.
\end{abstract}

Keywords: esthetics, collagen stimulators, dermal fillers, Ellansé ${ }^{\circledR}$, polycaprolactone, safety

\section{Introduction}

Two domains which have dramatically expanded in recent years, leading to both major biomedical advances and futuristic perspectives, are tissue engineering and esthetics. Both share a common approach based on biomaterials, polymers in particular. In esthetics, this is illustrated by the recent development of a new filler, the main component of which is polycaprolactone (PCL), a biodegradable and bioresorbable polymer, that possesses collagen-stimulating properties.

According to the latest statistics of the American Society of Plastic Surgeons (ASPS), in the non-surgical procedures, 2,671,130 injectable procedures were performed in 2018 , showing a $39 \%$ increase in the past 5 years. ${ }^{1}$ Minimally invasive
Correspondence: Marie-Odile Christen BEHAVIOR, 27 Avenue Marceau, Paris 75II6, France

Tel +33 680998336

Email christen.marieodile3@gmail.com 
procedures have increased by $228 \%$ since $2000 .{ }^{1}$ Dermal fillers are usually classified as permanent (eg, poly(methyl methacrylate)) or non-permanent (eg, collagen, hyaluronic acid). ${ }^{2,3}$ Although usually well tolerated and inducing only mild and temporary injection site reactions (eg, hematoma, redness or edema), dermal fillers can also sometimes trigger delayed reactions. Permanent materials are not recommended for esthetic purposes in many countries and when non-permanent dermal fillers are used, repeated injections are needed to maintain benefit. ${ }^{2,3}$ In search for a product with the most optimal safety and efficacy and the longest duration of action, a new generation of fillers emerged in the 2000s. These fillers, also known as collagen stimulators, are characterized by their long duration of action, and biostimulatory properties: the increased collagen production that follows their implantation extends their action duration. ${ }^{4}$ In 2009 , a novel collagen stimulator (Ellansé ${ }^{\circledR}$, Sinclair Pharma, London, UK) obtained the CE Marking and was introduced in Europe and many of the leading countries in esthetics worldwide. This collagen stimulator is composed of PCL microspheres suspended in an aqueous carboxymethyl cellulose (CMC) gel carrier. ${ }^{5}$ It is the only PCL-based filler. Interestingly, PCL is a known polymer belonging to the aliphatic polyesters, extensively investigated and used; it presents the advantage of a slower degradation than polylactic acid (PLLA) or polyglycolic acid (PGA), which both belong to the same chemical family. ${ }^{6,7}$

The present paper therefore shows how PCL, a wellknown polymer, has, decades after its first synthesis, led to the creation of an innovative, safe and long-lasting collagen stimulator (PCL filler) playing an important role in the expanding field of esthetics. The links between scientific and clinical knowledge and human use are presented to document and support safety and efficacy.

\section{Materials and Methods}

The method used for this article was based on literature surveys and the authors' personal knowledge of the various aspects covered. In respect of PCL properties and past, present and future applications in the biomedical field, given the numerous publications, the search focused on reviews and recent publications illustrating some of these biomedical applications. Some reviews were critical to this evaluation. With regards to the PCL-based collagen stimulator (PCL-filler) safety and efficacy, a literature search was conducted using the Medline, Scopus, and ClinicalTrials.gov databases, covering the period up to March 2019. No language restrictions were applied. The search terms used were "polycaprolactone" and "dermal filler", and "polycaprolactone" and "collagen stimulator". All identified articles were read and analyzed. To assess safety, vigilance data corresponding to a survey of reported adverse events worldwide were also used and recommendations for treatment of PCL-filler adverse events provided. Finally, in terms of safety in the context of clinical practice, recent recommendations and reviews on the prevention and management of adverse events related to soft tissue fillers were also selected.

\section{Polycaprolactone Is a Well-Known Polymer PCL Possesses Specific Characteristics}

PCL is a biocompatible, biodegradable, bioresorbable polymer, an aliphatic polyester belonging to the poly- $\alpha$-hydroxy acid group, in the same chemical group as polylactic and polyglycolic acids. It was first synthesized in the early 1930s by ring-opening polymerization of the cyclic monomer of $\mathcal{E}$ caprolactone. ${ }^{7,8} \mathrm{PCL}$ is made of a chain of a repeated singleunit sequence of $\mathcal{E}$-caprolactone $\left(\mathrm{C}_{6} \mathrm{H}_{10} \mathrm{O}_{2}\right)_{\mathrm{n}}$. The length (n) of the PCL chain or the corresponding molecular weight of the polymer determines the time of its degradation via esterbond hydrolysis and its persistence. PCL is a hydrophobic, semi-crystalline polymer, with a glass transition temperature of $-60^{\circ} \mathrm{C}$ and low melting point ranging from $59^{\circ}$ to $64^{\circ} \mathrm{C}$. It has also better viscoelastic properties than other biodegradable polymers, and is thus easy to manufacture and manipulate, allowing a large range of structures (microspheres, fibers, micelles, films, nanofibers, foams, etc.). It can also be easily blended with other polymers to produce copolymers exhibiting different physicochemical properties and biodegradability. Several reviews have been dedicated to PCL. ${ }^{7-13}$

\section{PCL Safety Is Based on Its Physicochemical Characteristics}

PCL is biocompatible. In vitro and in vivo tests have been carried out according to state-of-the-art standards (ISO 10993) to evidence the safety of PCL when placed in contact with human tissues and fluids.

PCL is biodegradable and bioresorbable. Biodegradation and bioresorption correspond to product degradation and total elimination from the body, respectively. Degradation of the implanted PCL devices involves hydrolysis of the ester bonds of the polymer chains. ${ }^{714-18}$ Hydrolytic degradation is a 2-phase process. In the first phase, by penetrating the polymer bulk, water causes chain scission. This phase shows 
a controlled, and predictable first-order linear pattern, dependent on the water permeability and length of the polymer. It follows a kinetic law whereby length continuously and linearly decreases with time $(t)$ via chain scission: $M_{n}=M_{n, o}$ $\mathrm{x} \mathrm{e}^{-\mathrm{kt}}$ where $\mathrm{t}=$ time, $\mathrm{Mn}=$ molecular weight, and $\mathrm{k}=$ the average rate constant for chain scission. The short second phase starts when the polymer is more highly crystalline and reaches a chain length of a low molecular weight of around 3000-5000 Da, allowing the small fragments to diffuse through the polymer matrix. The degradation end products $\left(\mathrm{CO}_{2}\right.$ and $\left.\mathrm{H}_{2} \mathrm{O}\right)$ are totally eliminated from the body. ${ }^{7,14,18}$

\section{PCL Safety Is Supported by Its Numerous Biomedical Applications}

The numerous advantages and wide array of functions of PCL systems have led to product development and stimulated scientists and physicians to use the polymer in a large range of applications, notably biomedical., ${ }^{7,19-22}$ The biomedical applications of implanted PCL detailed below, particularly those focusing on the new opportunities offered by PCL devices support the safety of PCL as used in the recently developed PCL-based collagen stimulator. ${ }^{7}$

Sutures were among the first devices made of synthetic absorbable polymers (including PCL), with the advantage of reproducible slow degradation in biological tissue. The copolymer of polycaprolactone and polyglycolide enters into the composition of the well-known monofilament suture Monocryl $^{\mathrm{TM}}$ (Ethicon, Inc.; Somerville, New Jersey, USA), widely used in several surgery fields for many years. ${ }^{23}$ It maintains high tensile strength and induces minimal tissue reaction after implantation in favor of its safety.

PCL is suitable for long-term drug delivery due to its high permeability to many drugs, excellent biocompatibility, slow biodegradability, and bioresorbability. Among the PCL drug release systems, the biodegradable contraceptive capsule Capronor ${ }^{\mathrm{TM}}$ made of PCL containing levonorgestrel has particularly been investigated regarding its design and long-term experimental (up to 2 years) and clinical development, providing important information on the global safety of PCL and confirming the PCL slow degradation process and the long-term safety of those drug release systems ${ }^{17}$ Many other drugs have been encapsulated in PCL microspheres, in particular: anticancer, ${ }^{24,25}$ antipsychotic, ${ }^{26}$ non-steroidal antiinflammatory, ${ }^{27,28}$ anti-hypertensive drugs ${ }^{29}$ and, others. A review presents numerous drugs released via PCLmicrospheres or nanospheres. ${ }^{10}$
PCL is used in implants in various tissues, extensively in 3D-scaffolds to promote repair and regeneration in bone, skin or other tissues ${ }^{12,21,30-33}$ and in engineering of autologous grafts. ${ }^{33}$

Tissue engineering can also use scaffolds produced by $3 \mathrm{D}$ printing, a fast-developing research area and application field in which PCL is a key player given its physicochemical (low melting point), mechanical properties (moldability) and longevity. 3D printing produces structures through successive layer deposition using a computerized process, to repair and replace tissues and/or organs. It is a very promising therapeutic approach which has now become a reality. ${ }^{34-39}$

PCL can save lives. The first design and implantation of 3D-printed PCL airway devices in humans originated from the Michigan University ${ }^{40}$ allowing physicians to save the life of a newborn ${ }^{40-42}$ and a woman, was treated by such device by a Chinese team, ${ }^{43}$ both suffering from tracheomalacia, a life-threatening condition. The role of PCL in tracheal surgery was recently reviewed. ${ }^{4,45}$ Scaffolds are also being investigated in congenital heart defect, gastric wall damage (hollow organ) and periodontal repair. ${ }^{46-48}$ The interest of this approach in orthopedics is tremendous: eg, meniscus replacement, affecting millions of people around the world. ${ }^{49-51}$ All these applications demonstrate how PCL is a key player in tissue engineering, providing therapeutic benefits particularly thanks to the new 3Dprinting technology; these multiple applications of various devices contribute to evidence PCL safety.

\section{PCL Is a Key Component of the Innovative PCL-Collagen Stimulator}

Historically, the successive dermal fillers made available were all designed to provide improved safety and longer action duration: collagens (with safety problems) and free hyaluronic acids (disappearing very rapidly in vivo, as collagens), cross-linked hyaluronic acids (with improved duration) and collagen stimulators (with the longest action duration). In the collagen stimulators, the polymer-based products have the longest action duration. Ellansé (Sinclair Pharma, London, UK), the PCL-based collagen stimulator (PCL-filler) has a longer action duration than other collagen stimulators used in esthetics, such as Sculptra ${ }^{\circledR}$ (Galderma, Lausanne, Switzerland), based on polylactic acid polymer, both having a longer duration than Radiesse $^{\circledR}$ (Merz Pharma, Frankfurt am Main, Germany), made of calcium hydroxyapatite belonging to a different 
chemical group, the ceramics. This characteristic among others contributes to clinical product differentiation.

In 2009, the PCL-filler received CE marking, as a Class III medical device. It is indicated for subdermal implantation in the face for long-lasting correction of facial wrinkles, aging signs or any facial age-related conditions, and for hand rejuvenation. This is the first and currently the sole collagen stimulator that is made of PCL. The regular PCL round-microspheres with smooth surface (Figure 1) in its composition ( $30 \%$ by volume) are homogenously suspended in a tailor-made aqueous CMC gel carrier ( $70 \%$ by volume). The CMC gel is responsible for the immediate effect; the microspheres for the sustained effect by collagen production and scaffold formation. CMC is a well-known non-toxic cellulose derivative extensively used. CMC has been classified as GRAS ("Generally Recognized As Safe") substance by the Food and Drug Administration (FDA), CMC and PCL successfully used for decades in humans in FDAapproved safe-to-use resorbable devices.

The original characteristics as well as the efficacy, duration of action and safety of the PCL filler are described below with a special focus on safety. As for any product, safety is based on the safety of the components and the finished product. Product presentations, Ellansé-S, -M, -L are available differing in their duration of action.

\section{The PCL Filler Is Biocompatible}

Biocompatibility refers to the product characteristics and properties and the type of interaction and cellular response

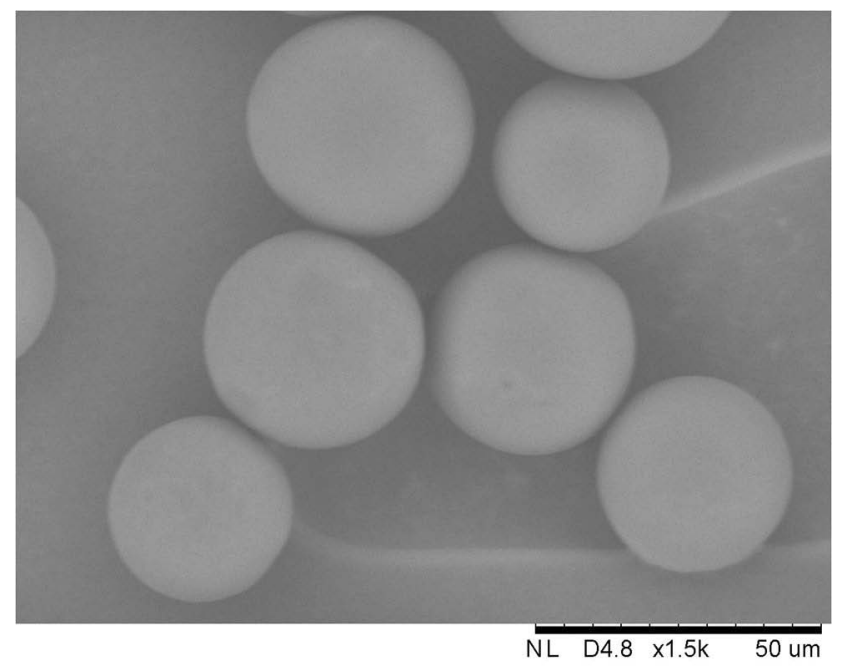

Figure I PolyCaprolactone microspheres' SEM picture Magnification I500x. Courtesy of Zijlstra P, Meadows J with permission. elicited when the material is implanted and gets in contact with the tissue. In the course of its development, the PCLfiller passed all standard tests (ISO 10993). In animals, most reported adverse events consisted of mild or moderate edema or mild ecchymosis, all resolving spontaneously within a few days.

\section{The PCL Filler Is Biodegradable}

The PCL-filler degradation occurs via hydrolysis and is characterized by a bulk degradation process when water penetrates the microspheres, causing progressive hydrolysis of the ester bonds from inside throughout the entire polymer matrix. First, the length and the molecular weight of the polymer chain decrease with time, while the mass, volume and shape of the implant remain unchanged; then, when hydrolysis has produced low molecular weight chains, diffusion of the small polymer fragments happens. ${ }^{7}$ In the microspheres, PCL displays both amorphous and crystalline regions; the amorphous regions are more easily hydrolyzed than the crystalline regions. Longevity of the microspheres ultimately depends on the hydrolytic breakdown of PCL crystalline regions. The distinguishing difference in the Ellansé range products is the chain length (molecular weight) of the initial PCL chains within the microspheres.

\section{The PCL Filler Possesses an Original Mechanism of Action}

The PCL-filler has a dual effect, an immediate effect and a sustained, long-term effect. The immediate effect is related to the CMC gel by the filling capacity of the injected volume and the highly hygroscopic properties of CMC. The rheological properties with high elasticity ( $G^{\prime}$ value around $1000 \mathrm{~Pa}$ ) contribute to the optimal network formation and placement in the tissue with even distribution of the microspheres, avoiding migration. The CMC gel is resorbed in 2-3 months. The immediate effect is followed by a sustained effect thanks to the collagen produced and the 3D-scaffold formed, made of the even distributed PCL microspheres embedded with collagen fibers interacting with the cellular environment and avoiding cluster formation. The collagen deposit leads to the prolongation of the sustained effect.

\section{The PCL Filler Is a Collagen Stimulator}

Collagen, the most predominant protein in human body and skin and a major component of the extracellular matrix (ECM) has not only an essential structural role of support but is a functional protein interacting at different 
cellular levels. In skin collagen type-I (85\%) and type-III $(10 \%)$ are predominant.

In aging, affecting fat, bone, muscles, and ligaments, loss of collagen, its disorganization and fragmentation play a central role in the associated skin changes ${ }^{52}$ with also changes in other components of the ECM. ${ }^{53,54}$ The fragmentation of the collagen fibers impairs its interaction with the fibroblasts, inducing modification of the cell morphology, thus reducing mechanical forces. Collagen decrease is accompanied by an increase in metalloproteinase levels. The collagen-related aging process has been extensively investigated and reviewed; few reviews are cited. ${ }^{52-59}$

The PCL-filler is a collagen stimulator, as demonstrated in animals and humans treated by the S- and/ or M-PCL products. Biopsies examined in histology using specific staining (Picro-Sirius Red) showed an increase in collagen and allowed collagen subtypes determination. Both the $\mathrm{S}$ and $\mathrm{M}$ products induced collagen production. In animal, the $\mathrm{M}$ product induced collagen type-III and type-I at early stage (measure at 9 months), and later predominantly collagen type-I, that deposits around the PCL microspheres (measure at 21 months) ${ }^{60}$ in accordance with the healing process sequence. Collagen production was confirmed for the first time in humans on biopsies taken at 13 months after injection of the M-product at the level of the temple of patients willing to undergo temple-lifting surgery. ${ }^{61}$ In a recent study, collagen production was further evidenced in humans on temple biopsy, after treatment with the M-product using a different injection technique. New collagen fibers were demonstrated by specific stainings and immunohistochemistry at 1-year post-treatment. Many fibroblasts were found near the PCL microspheres. Interestingly, new elastin fibers were also formed, and neovascularization with new capillaries observed as well. ${ }^{62}$ PCL-induced collagen typeI production was also shown by immunohistochemistry on human biopsies at 6 months (Figure 2A and B).

\section{The PCL Filler Effect Involves Original Cellular Responses}

The response to injection of the product, as with any injection, that creates an injury triggers a tissue repair process. The collagen induced by the PCL filler follows the healing cascade characterized by three main phases: inflammation, proliferation and remodeling; granulation tissue formation and early appearance of collagen type-
III is followed by long-term collagen type-I production and deposition, in the remodeling phase. ${ }^{63,64}$

The response to the material implanted in vivo elicits cellular and tissue responses. ${ }^{65,66}$ Host response includes protein coating of the material, macrophage migration, and encapsulation at around 3 weeks. Inflammatory reaction and wound healing pathway participate in this stepwise repair process. The host response corresponding to cellular interaction with the material is linked to the product characteristics and properties and to the type of tissue interaction when the material is implanted in contact with the tissue. This is part of biomaterial biocompatibility. ${ }^{65-67}$ The type and degree of the reaction between material and host depend among others on the properties of the implant: composition, size, shape, surface, roughness, porosity.

Phagocytosis indeed is dependent on the size of the microspheres: the smaller the particles, the faster they are phagocytosed, with a high degree of inflammation. The PCL-filler is made of PCL microspheres of $25-50 \mu \mathrm{m}$ size which protects them from phagocytosis. ${ }^{67}$ Not only the size but also the shape has been shown to greatly influence the tissue reaction. ${ }^{68}$ The shape, round or irregular determines the degree of reaction. The PCL microspheres are regular, spherical with a smooth surface, characteristics that are known to be optimal to minimize inflammatory reaction (Figure 1) ${ }^{67,68}$ Moreover, the shape of the microspheres is maintained during the first phase of bulk degradation, as a result of the PCL properties, as aforementioned; these particular characteristics allow the microspheres to be embedded with the newly formed collagen type-I fibers, creating a regular network that remains in place throughout PCL microspheres degradation. The collagen that is formed and deposited maintains the sustained effect.

The response to mechanical forces and cellular interactions is dependent upon the implanted material in the cellular environment creating a mechanical tension that stretches the fibroblasts which respond by producing collagen. The responses to cell-matrix (ECM), cell-cell, and cell-ECM-material interactions operate through many sensors and effectors using different signaling pathways. ${ }^{69-71}$ The cellular process known as mechanotransduction, which converts mechanical forces to intracellular signals and biological responses operating via collagen, is at the heart of mechanobiology, ${ }^{72-74}$ a field of fundamental importance which should deserve a more in-depth discussion particularly when involving biomaterials. This 

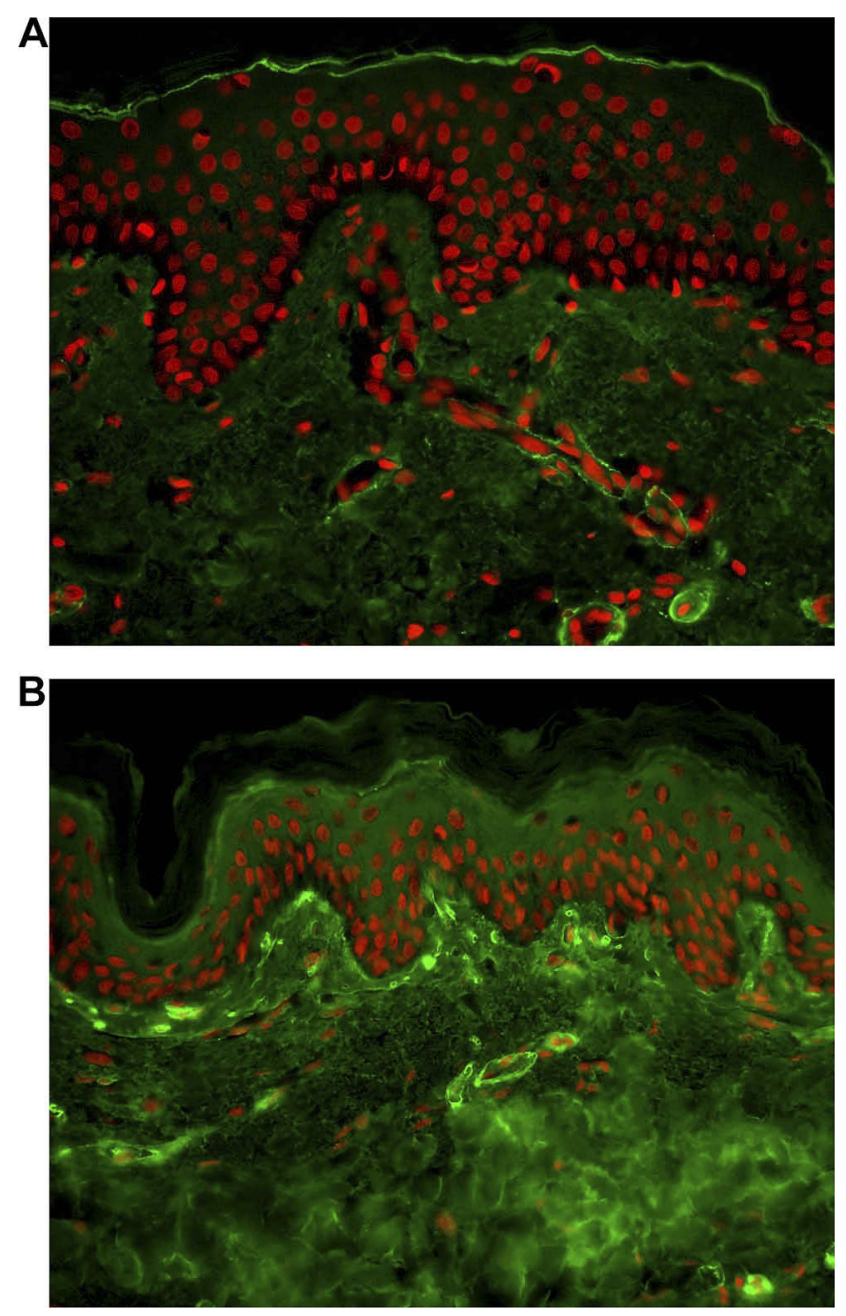

Figure 2 Immunohistochemistry of collagen type-I in human skin abdominal biopsies after PCL filler (6 months). (A) Control; (B) PCL treated. Courtesy from Piovano L, MO Christen and Bioalternatives co. with permission.

process can be viewed as the major contributor in the PCL-filler mechanism of action. Other cellular interactions such as cross-talk between fibroblasts and keratinocytes are under investigation and could explain other properties (skin quality), or with adipocytes in hypodermis.

In total, the PCL-filler is a collagen stimulator inducing biostimulatory effect with immediate and sustained effect. The collagen type-I produced and the specific scaffold formed with the microspheres contribute to its sustained volumizing effect.

\section{PCL-Based Collagen Stimulator Exhibits Long-Term Efficacy and Duration of Action}

Several clinical studies assessed the efficacy and duration of action of the PCL-based collagen stimulator; the
$\mathrm{S}$ and $\mathrm{M}$ products were commonly used in those studies. Patients were followed for 6 to 24 months, depending on the study design. The PCL-filler is presented in $1 \mathrm{~mL}$ sterile syringe.

The prospective randomized studies evaluated the effect of the product on nasolabial folds which is the main area tested in standardized clinical studies of dermal fillers. ${ }^{5,75-77}$ The efficacy of the PCL-based filler was assessed on the Wrinkle Severity Rating Scale (WSRS) and/or Global Aesthetic Improvement Scale (GAIS), by subjects and investigators and on the basis of photos. Satisfaction was also recorded by both subjects and investigators. A prospective, randomized, controlled study evaluating the efficacy, safety, satisfaction, duration of action of the PCL-S versus PCL-M filler for correction of nasolabial folds (NLFs) included 40 subjects followed at different times post-treatment: $3,6,9,12,15$, and 18 months. At 12 months the efficacy outcomes on GAIS showed improvement in $90 \%$ and $91.4 \%$ of patients, respectively. At 24 months PCL-M was more effective than PCL-S, showing sustained improvement for the entire 2 years study period. At 24 months patient satisfaction was high (81.5\% for PCL-M and $72.4 \%$ PCL-S). ${ }^{5,75}$ Another study, a randomized, prospective, blinded, split-face single center study was aimed at comparing PCL-S to a hyaluronic acid filler in 40 subjects followed up to 12 months. WSRS and GAIS results were significantly improved at 6, 9 and 12 months. ${ }^{76}$ These studies provide a proof of concept, demonstrating longer duration for the $M$ - than the S-product ${ }^{5,75}$ and longer action duration of the S-product than a hyaluronic acid filler. ${ }^{76}$ A recent European, multicentric clinical study was conducted, including 90 patients with moderate to severe NLFs followed for 18 months after single injection and no touch-up. At 12 months $84 \%$ of subjects had $\geq 1$-point improvement in WSRS. Significant improvement of GAIS was observed similarly both by the physicians and the subjects in more than $90 \%$ of subjects up to 12 months and in $81 \%$ of subjects at 18 months. Satisfaction evaluated by the physicians and the subjects was high. Natural effect was observed in $80 \%$ of the subjects at 12 months. Skin quality improvement was noted on several skin features (natural effect, skin smoothness, freshness, rested face, younger appearance); ${ }^{77}$ this confirms observations reported by many physicians in their clinical practice.

Clinical efficacy was also evaluated in other facial area and in hands. A recent case study investigated the effect of PCL filler to treat the descending soft tissue and contour 
defects in an Asian subject. The results showed improvement in facial volume in multiple tissue layers on photographs and 3D imaging (Vectra XT), achieving total facial rejuvenation from upper, midface and lower face 12 weeks posttreatment. ${ }^{78}$ The effect was also shown on forehead augmentation in 58 Asian subjects up to 24 months after injection of the product in several points into the submuscular layer using cannula. Forehead augmentation is very important to achieve a beautiful face and optimal younger appearance. ${ }^{79}$

A study using a different injection technique showed at the temple level increase in skin thickness using ultrasonography and histology, at 1 year, with a visible improvement of skin texture and skin pore size reduction, that can be related to neocollagenesis. ${ }^{62}$

Efficacy was also demonstrated for rejuvenation of the hands, an area of visible aging, in a pilot study. ${ }^{80}$

Together, these clinical studies demonstrated the longterm efficacy of the PCL-filler in different area and conditions and improved skin quality. Its long duration of action, as expected from its characteristics and scaffold formation, was evidenced; collagen contributes and maintains the sustained effect, Ellansé-S duration of action is at least 18 months, Ellansé-M at least 24 months.

Long clinical experience in daily practice worldwide for 10 years has confirmed the volumizing and rejuvenating effect found in the clinical studies, with immediate and sustained effects. The product is injected in subdermal or supraperiosteal planes, depending on the area to be treated. Experts' recommendations had been published describing the injection techniques and modalities, as well as the area to treat or to avoid. ${ }^{81}$ The main clinical treatment outcomes are volume restoration, contour redefinition, skin rejuvenation, skin quality, wrinkle reduction.

\section{PCL-Based Collagen Stimulator Has a Good Safety Profile PCL Filler Safety Is Shown in Clinical Studies}

The clinical studies simultaneously evaluated safety. Globally, no serious adverse events or granuloma or vascular complications were reported, with a few immediate injection-related reactions, mainly edema or ecchymosis; these were usually mild and spontaneously resolved within a few days without intervention. The authors stated that the treatment was well tolerated. ${ }^{62,75-80}$

In the European clinical study, safety being the primary end point, the injection site reactions (ISRs) reported occurring immediately or rapidly after injection were similar to those encountered after injection of any filler; swelling and bruising/ecchymosis of mild intensity were noted and they disappeared in 2 to 4 days. In 2 subjects minor side effects ecchymosis in one case and ecchymosis/edema in the other lasted 15 days and 8 days, respectively; 2 adverse events were likely to be attributable to the PCL filler: only one in the 90 subjects that was reported over the 18 months follow-up had to be treated: it was 1 case of subcutaneous nodule on one NLF side; it resolved after corticoid injection. The other one, a case of induration of mild intensity on both nasolabial folds, disappeared spontaneously. This study was extended to evaluate the long-term safety up to 30 months in a subset of the study population in 29 subjects, showing the absence of delayed adverse events. ${ }^{82}$

In total, the long-term safety of the PCL-filler was shown during the clinical trials and confirmed in the clinical study following safety up to 30 months (last time point), complying with the recommendations of health authorities to evaluate the long-term safety of dermal fillers, to better estimate the risk, even low, of late complications of products and procedures in esthetics.

\section{PCL Filler Safety Is Supported by Its Daily Clinical Practice}

The safety of the PCL filler observed in the clinical studies is confirmed by the post-market surveillance (PMS) data based on the long clinical experience worldwide. Since its launch in 2009, a global vigilance system has ensured follow-up and reporting of adverse events. Analysis of the PMS data collected from 2009 to December 2017 provides a good picture of its safety profile. During this period, 355 adverse events were reported, while more than 600,000 syringes were sold: ie, a low adverse event rate of $0.056 \%$ or 1 adverse event per 1769 syringes. ${ }^{83}$ Today 1 million syringes have been used for treatment with a similar low adverse event rate. Adverse event rates, for the PCL-based products, were similar. Most adverse events were minor and not considered serious enough to meet vigilance reporting criteria. They mainly comprised edema/swelling $(0.02 \%)$ or lumps/nodules $(0.023 \%)$ (Figure 3$)$. Edema/swelling was usually of mild or moderate intensity and spontaneously resolved in a few days. Lumps/nodules resulted from abnormal tension applied to the tissue and seem usually to be caused by technical error (eg, bolus $>0.2 \mathrm{~mL}$, or too superficial injection). Different injection modalities to avoid 


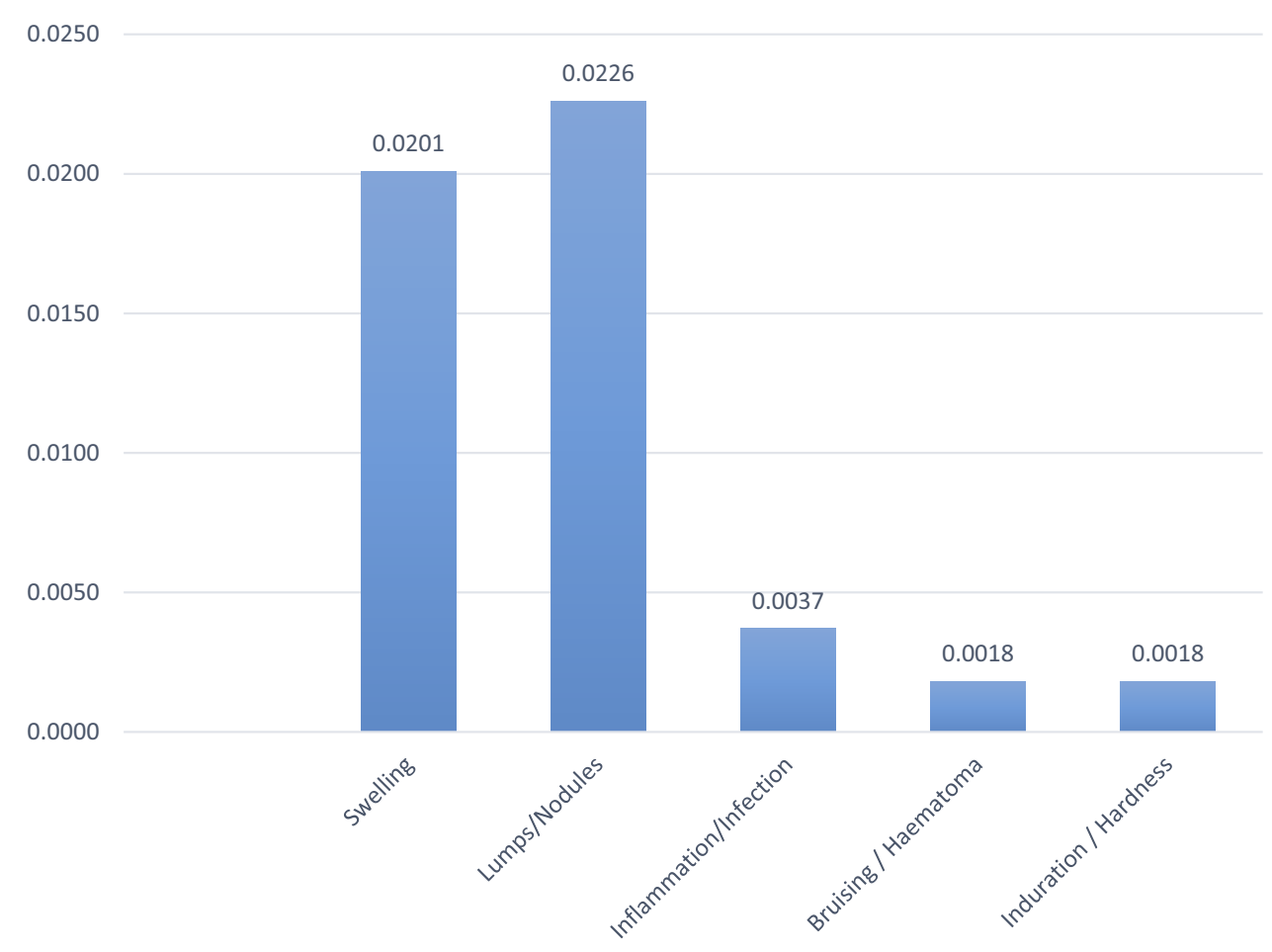

Figure 3 Post market surveillance (PMS)-2009-December 2017 (adverse event rates (\%) per type). @20I8. Sinclair. Reproduced from Sheikh, J Smith. Internal data 20I8. ${ }^{83}$

nodule formation that physicians should follow are presented in Table 1.

No unexpected adverse events have been reported. The safety profile of the PCL-based collagen stimulator is good. Considering the few available published data on complications, a case report discussed a late reaction in a Korean patient, 3 years post-treatment with the PCL-filler but the case was very poorly documented. ${ }^{84}$ Another case described as a granuloma, the first one, was reported in a subject who observed tiny nodules at the injection sites 1 year after facial treatment, and waited for follow-up visit 2 years posttreatment; the patient refused to consent to treatment and was lost to follow-up; bacterial contamination was detected on biopsy. ${ }^{85}$ A retrospective case analysis considered discoloration, xanthelasma-like reaction after dermal fillers

Table I PCL Filler Injection Modalities to Avoid Nodules

\begin{tabular}{|l|}
\hline To Avoid Nodules \\
\hline - Inject bolus $\leq 0.2 \mathrm{~mL}$ \\
- Inject slowly \\
- Do not inject within muscles, lips or eyelids \\
- Be very cautious within thin skin \\
- Do not inject large volumes to avoid unnecessary tension \\
- In hands, try to stay within the most superficial lamina: stay above \\
the veins; use cannula \\
\hline
\end{tabular}

injection, hyaluronic acid, calcium hydroxyapatite and one case with PCL in lower eyelid. ${ }^{86 .}$ It is a very rare reaction with dermal fillers and eyelid treatment is not an indication for PCL; it should not be injected in the periorbital region. ${ }^{81}$ A review on the complications with the PCL filler, collected by phone interviewing, reporting by patients or by observation at follow-up visits, was done in Korea in 780 treated subjects from April 2015 to May 2018 with a total of 1111 treatments, showing good safety in this large patient group. Edema and bruising, as after any injection, were the most common. The complication rate was low, with no incidence of intravascular complication, nodules and/or granuloma during the 3 years' observation. ${ }^{87}$

Taken together, the results of the clinical studies and the treatment outcomes in daily clinical practice confirm the good long-term efficacy, long action duration and good long-term safety profile of the PCL-filler injected in humans seeking for esthetic treatment. Natural results and skin quality improvement were evidenced.

\section{PCL-Based Collagen Stimulator Safety via Prevention and Treatment Recommendations}

Although they usually have a good safety profile, dermal fillers can be associated with a risk of both short- and 
long-term complications and growing use increases the risk. Physicians have to be aware of patient-, product-, environment- and procedure-related factors for avoiding adverse events. Prevention and management of complications of the PCL filler will be presented in a general frame in light of the knowledge and vast experience acquired on complication prevention and treatment of dermal fillers in the recent years.

Recommendations for PCL filler complication treatment are provided (Figure 4).

Indeed, prevention and treatment of adverse events are essential for optimal esthetic outcomes in safe conditions.

To prevent adverse events, treatment with the PCLbased collagen stimulator, as with other dermal fillers, has to follow strict rules and general recommendations covering the various steps of the procedure. A group of physicians discussed the main prevention measures in a dedicated article, ${ }^{88}$ prevention and management of complications were also dealt with, in expert reviews and expert panel consensus reports. ${ }^{89-105}$

\section{Prevention of Adverse Events Is the Cornerstone of Safety}

Prevention covers all the steps from pre-procedural to procedural and post procedural cares.

Regarding the patient, proper selection is a key factor. A publication specifically focused on "patient factors influencing complications". 92 Recommendations for preprocedural care begin with thorough patient assessment (medical history of past and current diseases, previous and ongoing medical and esthetic treatments) and an understanding of the patient's expectations; esthetic assessment allows to define a suitable treatment plan. This first step should be patient screening: "Selecting appropriate patients, or perhaps more importantly, not treating inappropriate patients, is the first and a crucial step in avoiding complications with dermal fillers". 92

Regarding the product, right selection is essential. The Instructions for Use (IFU), including among others the contraindications must be carefully followed. Conditions contraindicating or warranting caution in the use of dermal fillers in general have been described in detail. ${ }^{92,105}$

The theater, environment and injection sites should be clean and treatment performed in aseptic conditions, to prevent infection. As with any transcutaneous injection, infection is always possible, even if the rate with the PCLbased collagen stimulator is extremely low. Standard precautions associated with injectable materials are thus to be followed.

Moreover, the PCL-filler must be injected only by recognized and trained physicians thoroughly familiar with the product and injection modalities. ${ }^{81}$ Training concerns anatomy, product characteristics and mechanism of action (integrating the fact that the PCL-based dermal filler is a collagen stimulator), injection techniques and practice. Attention should be paid to danger zones, described by several experts; in a recent publication the authors focused on the glabella/ brow, temporal region, perioral region, nasolabial fold, nose and infraorbital region and proposed techniques to maximize safety. ${ }^{106}$ Lips, glabella and periorbital region (eyelids, under-eye dark circles, crow's feet) have to be avoided with the PCL filler as generally with collagen stimulators.

The patient has to be carefully informed of the procedure and risks prior to treatment and must sign an informed consent form. An individualized treatment plan is to be defined before the start of the procedure. Before and after high-quality photos are important for assessment and effect evaluation. In their recommendations for the PCL-based collagen stimulator, a group of experts recently provided details on injection modalities and techniques according to area (upper, mid and lower face or hands), with a description of the methods of injection, including volume and depth of injection and the device (cannula, needle) to be used. ${ }^{81}$

Prevention of adverse events also depends on postprocedural care. The physician must inform the patient that they will have to keep their face clean, and avoid make-up, exposure to heat (eg, sauna) or extreme cold weather, sun or lamp exposure, alcohol, and swimming or bathing for the first $24 \mathrm{hrs}$.

\section{Management of Adverse Event Is Mandatory: Recommendations}

Although severe adverse events with dermal fillers are rare, it is mandatory for physicians to know how to handle those effects in case they occur. Many experts and experts' panels have provided recommendations for treating adverse events, offering guidance for management that physicians should use in their daily clinical practice and eventually adapt according to their patients' condition and response to treatment. ${ }^{89-105}$

First, it is important to be able to identify and localize the culprit product. The PCL filler has been recently identified by ultrasound, presenting a specific sonographic morphology characterized by a deposit showing a hypoechoic matrix 


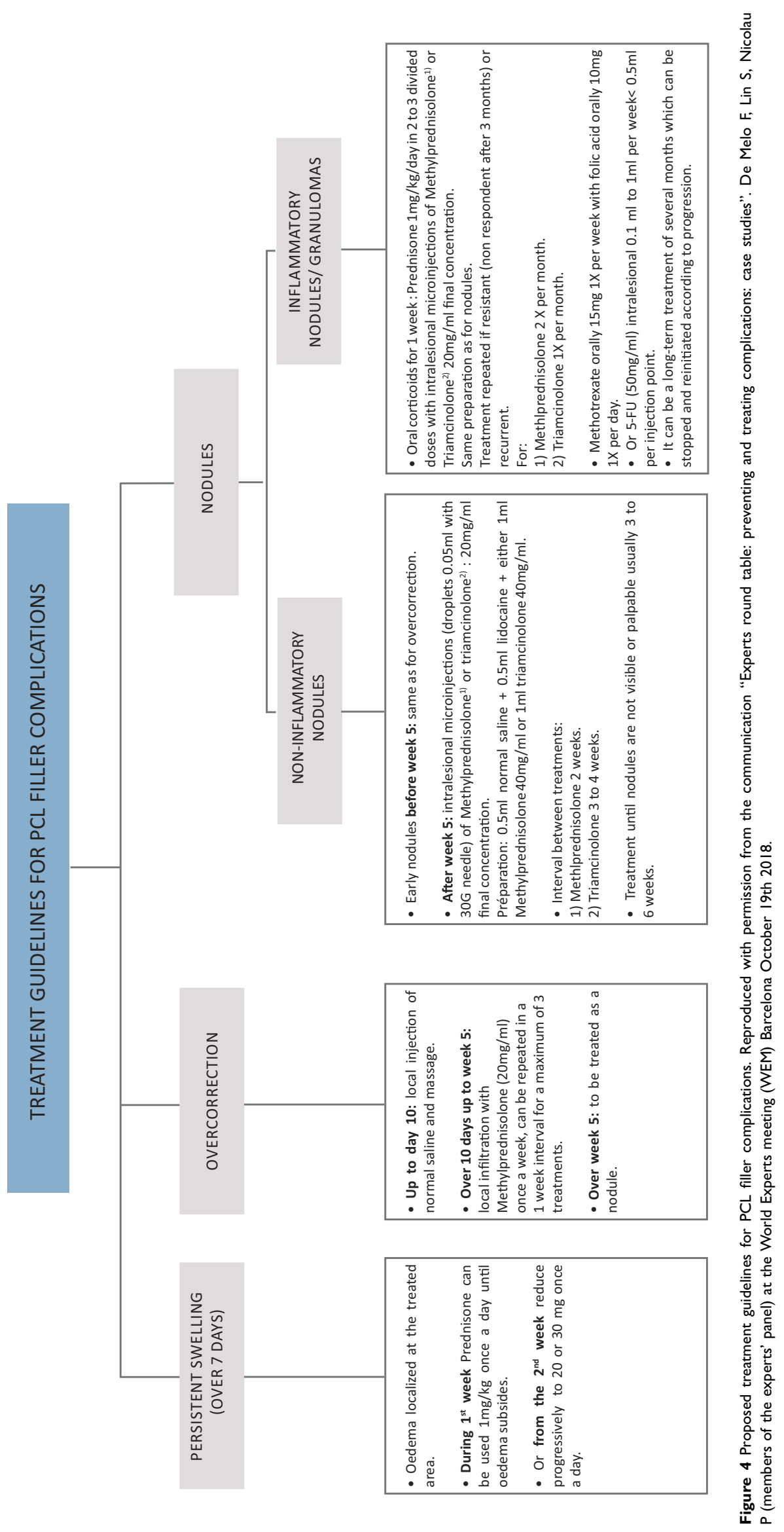


and multiple bright hyperechoic spots with mini-comet-tail artifacts. ${ }^{107}$ This allows the PCL filler to be differentiated from other fillers (HAs), poly(methyl methacrylate), and calcium hydroxyapatite. ${ }^{107,108}$ A case described the use of ultrasonography-guided curettage of PLLA filler-induced granuloma. $^{109}$ and a recent publication, the use of ultrasounds for safety purpose in the case of HAs injection. ${ }^{110}$ This technique is advantageous for improving diagnosis, identifying the injected product, guiding adverse event treatment and following evolution.

The present section focuses firstly on the treatment of the most frequent minor side effects such as swelling/ edema and nodules/lumps encountered with the PCL filler which are anyway rare ${ }^{83}$ and common to all dermal fillers. Then, overcorrection and management of late adverse events, inflammatory nodules/granuloma are presented based on clinical practice and recent literature on fillers. Figure 4 summarizes the proposed treatment guidelines for the management of those side effects.

Swelling/edema is a normal inflammatory reaction to the trauma caused by the injection or large volume injected that should disappear within 5 to 7 days. A panel of physicians recommended prophylaxis with anti-inflammatory enzymes (Wobenzym Vital 2 capsules per $12 \mathrm{hrs}$; bromelain $300 \mathrm{mg} / \mathrm{kg}$, divided in 3 doses); arnica/gelsemium 4-5 pills per 24 hrs for 3-4 days; cold compresses (for about 5 mins) and anti-inflammatory drugs (NSAIDs and streptokinase/ streptodornase) for treatment of moderate cases. ${ }^{105}$

Swelling is considered as a complication only if it persists longer or is of major importance. Treatment of persistent edema localized at the treated zone that lasts more than 7 days until 2 weeks is logically based on oral corticosteroids. For the PCL-based collagen stimulator, prednisone can be used $1 \mathrm{mg} / \mathrm{kg}$ once a day until edema subsides and from the second week the dosage is reduced progressively to 20 or $30 \mathrm{mg}$ once a day (Figure 4).

For dermal fillers in general malar edema that is longlasting responds poorly to treatment and experts recommend prevention (selecting patient and filler, limiting filler volume, placing the product deep). ${ }^{111}$

Nodules should not be confused with granulomas; nodules are non-inflammatory and hard, localized at the injection sites, pea-shaped and not increasing in size. ${ }^{112}$ Nodules generally resolve spontaneously. Treatment is dependent on time of onset. A "wait and see" attitude is recommended, especially if the nodules are not visible. ${ }^{113}$ Nodules/lumps occurring early after injection are generally related to a technical error: a too superficial injection creating tissue tension, large volumes injected in focused areas, injection within scar tissue, or injection close to or within the dermis. Vigorous massage, with injection of a saline solution with or without lidocaine, or subcision is used in early nodules following injection. Intralesional microinjection of corticosteroids (various can be used) is the standard treatment in case of non-response to massage or with later onset. Treatment generally needs to be repeated. Nodules occurring with PCL-filler after week 5 can be treated by intralesional microinjections of methylprednisolone or triamcinolone $20 \mathrm{mg} / \mathrm{mL}$ final concentration with interval between treatments of 2 weeks and 3 to 4 weeks, respectively, until they are not visible, usually 3 to 6 weeks (Figure 4).

In case of overcorrection to be distinguished from swelling, which is very rare, given the recommendation not to overcorrect with a collagen stimulator, treatment has similarities and depends also on time of diagnosis. For the PCL filler, treatment given, with different options depending on whether it occurs at early stage up to day 10 (injection of saline and massage) or whether it is observed over 10 days up to week 5 (local infiltration of methylprednisolone) or after week 5 (treatment as a nodule). (Figure 4)

Inflammatory nodules/granuloma are very rare but severe adverse events. It is important to differentiate them from nodules and to know the possible causes as well as possible treatment. ${ }^{112,114,115}$ They are a secondary lateonset chronic inflammatory reaction of varying etiology, occurring 6 to 24 months after injection. They can persist for a long time if not treated. Histologically, they present the characteristics of a foreign-body reaction, they grow in size over time, fingerlike in the surrounding tissue and affect all injected sites simultaneously; they can be accompanied by skin discoloration and edema and are rather soft. The sequence of events leading to granuloma has been well described. ${ }^{116,117}$ A tabulated overview of some of the treatment protocols from experts' recommendations published in the recent past years has been written by the authors of the present article and is provided in Table 2, showing a similarity of approach with some adaptations depending on the experts and conditions; they are based on their application to dermal fillers, some dedicated to hyaluronic acids and their favorable outcomes in resolving these complications. Treatment is based on intralesional corticosteroids (high-dose triamcinolone mixed with lidocaine and 5-fluorouracil (5-FU)) is preferable to prevent recurrence and skin atrophy. ${ }^{112}$ Oral corticosteroids are often associated, especially for recurrent granuloma. Surgical therapy 
Table 2 Recommendations for Treatment of Dermal Fillers Induced Inflammatory Nodules/Granuloma

\begin{tabular}{|c|c|}
\hline References & Treatment Recommendations \\
\hline Graivier et al $(2018)^{103, t, \neq}$ & $\begin{array}{l}\text { Intralesional triamcinolone, Kenalog } 40 \pm 5 \mathrm{FU} \text { combination ( } 50 / 50 \text { mixture) which can be mixed with lidocaine (Q weekly or } \\
\text { every } 2 \text { weeks) repeated at } 3 \text { - to } 4 \text {-week interval and monitored. Collagenase for particulate fillers and oral medications } \\
\text { (corticosteroids or allopurinol) may be used. If no progression, excision, laser melting. } \\
\text { In case of infection, antibiotics: oral quinolone/macrolides (Cipro } 500 \mathrm{mg}+\text { Biaxin } 500 \mathrm{mg} \mathrm{BID} \text { ) up to } 6 \text { weeks. In case } \\
\text { of failure or worsening, IV vancomycin-lincomycin/teicoplanin every other day for } 10 \text { days followed by oral antibiotics } \\
\text { for } 10 \text { days. }\end{array}$ \\
\hline $\begin{array}{l}\text { Urdiales-Galvez et al } \\
(2018)^{105, \dagger}\end{array}$ & $\begin{array}{l}\text { Oral or intralesional corticosteroids; if needed, addition of } 5 \text {-FU. } \\
\text { In case of failure, surgical excision. } \\
\text { In case of infection antibiotic treatment: clarithromycin } 500 \mathrm{mg} \text { plus moxifloxacin } 400 \mathrm{mg} \text { twice daily for } 10 \text { days, or } \\
\text { ciprofloxacin } 500-750 \mathrm{mg} \text { twice daily for } 2-4 \text { weeks, or minocycline } 100 \mathrm{mg} \text { once daily for } 6 \text { months. }{ }^{99}\end{array}$ \\
\hline $\begin{array}{l}\text { Philipp-Dormston et al } \\
(2017)^{102, *, \dagger}\end{array}$ & $\begin{array}{l}\text { Antibiotics in case of infection or suspicion of infection; if no response, hyaluronidase to be added. } \\
\text { Steroids or other immunosuppressants only if no response to previous treatment or if histopathological proof of granuloma. }\end{array}$ \\
\hline $\begin{array}{l}\text { Abduljabbar et al } \\
(2016)^{96, *,+, \neq}\end{array}$ & $\begin{array}{l}\text { Intralesional hyaluronidase for HA. Systemic and intralesional corticosteroids, systemic oral antibiotics. } \\
\text { Intralesional 5-FU and laser. }\end{array}$ \\
\hline Signorini et al $(2016)^{99, *, t, \neq}$ & $\begin{array}{l}\text { Hyaluronidase in case of HA. Empiric antibiotics should be considered: clarithromycin } 500 \mathrm{mg}+\text { moxifloxacin } 400 \mathrm{mg} 2 \times / \\
\text { day for } 10 \text { days OR ciprofloxacin } 500 \text { to } 750 \mathrm{mg} 2 \times / \text { day for } 2 \text { to } 4 \text { weeks OR minocycline } 100 \mathrm{mg} \text { once/day for } 6 \text { months. } \\
\text { Oral or intralesional corticosteroids after infection ruled out or quiescent; in case of repeated failure, surgical resection is } \\
\text { the treatment of choice. Laser }\end{array}$ \\
\hline De Boulle et al $(2015)^{92, \dagger}$ & $\begin{array}{l}\text { Intralesional corticosteroids (betamethasone } 5 \mathrm{mg} / \mathrm{mL} \text { or triamcinolone } 10-40 \mathrm{mg} / \mathrm{mL} \text { for } 10 \text { days up to } 4 \text { weeks) } \\
\text { can be considered, although care needs to be taken to avoid skin atrophy. } \\
\text { For persistent cases, additional measures can include a series of injections of } 5 \text {-fluorouracil }(50 \mathrm{mg} / \mathrm{mL} \text { ) in } \\
\text { combination with corticosteroids and/or lidocaine (I:3), methotrexate, local tacrolimus, cortivazol, allopurinol, } \\
\text { colchicine, isotretinoin, imiquimod, laser-assisted removal, or ultimately resection by surgery as a last resort. } \\
\text { In case of infection treatment with antibiotics starting with macrolide or tetracycline (cf ref to several authors) }\end{array}$ \\
\hline Lee et al $(2015)^{117}$ & $\begin{array}{l}\text { Intralesional injection of corticosteroids: preferably, high-dose of triamcinolone mixed with lidocaine to prevent } \\
\text { recurrence; IL 5-FU has been used as well as bleomycin. } \\
\text { Use of a } 0.5 \mathrm{~mL} \text { or I mL insulin syringe with a } 30 \text { Gauge needle for intralesional injection is recommended. } \\
\text { Injection of small amount gradually moving from the periphery to the central area, as granuloma tends to spread. } \\
\text { Systemic therapy: systemic corticosteroid injection for recurring granuloma with higher dose than those used in } \\
\text { local injection. Oral prednisone: starting dose } 30 \mathrm{mg} / \text { day and maintenance dose of } 60 \mathrm{mg} / \text { day to prevent recurrence. } \\
\text { Minocycline combined with oral or intralesional corticosteroids effective for widespread inflammatory granulomas. } \\
\text { Systemic treatment with allopurinol, colchicine and cyclosporine also reported. } \\
\text { Surgical therapy: excision not a first choice. Resection of localized sclerosing granuloma can be attempted }\end{array}$ \\
\hline Rzany et al $(2015)^{94, \dagger}$ & $\begin{array}{l}\text { Inject steroids: usually } 10 \mathrm{mg} \text { triamcinolone acetanide diluted for example with lidocaine, either I:4 or I:5 and/or } \\
5 \text {-FU diluted I:I with lidocaine } \\
\text { Or Start oral corticosteroid treatment as pulse (eg, methylprednisolone): } \\
\text { Methylprednisolone } 60 \mathrm{mg} \times 2 \text { days; } 40 \mathrm{mg} \times 2 \text { days; } 20 \mathrm{mg} \times 2 \text { days then off for I week. Extend dose if required; eg, } \\
40 \mathrm{mg} \mathrm{I} \times \mathrm{I} \text { or, if more inflammatory, up to } 100 \mathrm{mg} 2 \times \mathrm{I} \text { over } 3-6 \text { weeks } \\
\text { And/Or doxycycline } \\
\text { And/Or fumaric acid tablets } \\
\text { Excision if needed - Laser diode and } \mathrm{CO}_{2} \text { followed by extrusion }\end{array}$ \\
\hline Kim et al $(2014)^{91,+, \ddagger}$ & $\begin{array}{l}\text { First choice is massage and intralesional corticosteroids } \\
\text { If needed, combination with } 5 \text {-FU and corticosteroids. } \\
\text { If failure, surgical resection. } \\
\text { If no resolution biofilm has to be considered and treatment with antibiotics a quinolone and third generation } \\
\text { macrolide, } 5 \text {-FU or excision to be performed }\end{array}$ \\
\hline
\end{tabular}

(Continued) 
Table 2 (Continued).

\begin{tabular}{|c|c|}
\hline References & Treatment Recommendations \\
\hline $\begin{array}{l}\text { Funt et al }(2013)^{90, \ddagger} \\
(2015)^{93, \ddagger}\end{array}$ & $\begin{array}{l}\text { Intralesional corticosteroids (triamcinolone, betamethasone, or prednisolone). } \\
\text { Add 5-FU to corticosteroids if lesions unresponsive } \\
\text { Surgical resection is last resort } \\
\text { Biofilm: antibiotics (ciprofloxacin, clarithromycin) for } 4-6 \text { weeks. Do not use intralesional corticosteroids } \\
\text { Extract material with } 16 \text {-gauge needle + syringe and negative pressure } \\
5 \text {-FU injection: } 50 \mathrm{mg} / \mathrm{mL}(0.5 \mathrm{cc} \text { ) every } 4 \text { weeks. } \\
\text { If induration persists after the above, consider laser lysis, incision, and washing out cavity with antibiotics } \\
\text { Surgical resection is last resort }\end{array}$ \\
\hline Ozturk et al $(2013)^{89,+, \neq}$ & $\begin{array}{l}\text { Massage and intralesional corticosteroids or incision and drainage. Excision } \\
\text { In case of biofilm, prolonged use of antibiotics (a quinolone and a third-generation macrolide), } \\
\text { intralesional 5-FU and intralesional laser at } 532 \text { or } 808 \mathrm{~nm}\end{array}$ \\
\hline $\begin{array}{l}\text { Lemperle et al }(2006)^{1 / 2} \text {, } \\
(2009)^{115, \dagger}\end{array}$ & $\begin{array}{l}\text { Proven corticosteroids for granuloma are: triamcinolone (Kenalog } 20 \text { to } 40 \mathrm{mg} \text { IL- betamethasone (Diprosone)) } 5 \\
\text { to } 7 \mathrm{mg} \text { IL- methylprednisolone (Depo-Medrol) } 20 \text { to } 40 \mathrm{mg}-\text { Diprosone }(3,5 \mathrm{mg})+5 \text {-FU ( } 80 \mathrm{mg}) \text { lidocaine: } 0.5 \mathrm{~mL} \\
+1.6 \mathrm{~mL}+\mathrm{ImL} \mathrm{IL}-\text { Kenalog + 5-FU: ( } 10 \mathrm{mg} / \mathrm{mL})+5 \text {-Fu ( } 50 \mathrm{mg} / \mathrm{mL}) \mathrm{IL} \text {. Intralesional reinjection if no resolution after } \\
3 \text { to } 4 \text { weeks. } \\
\text { The treatment of choice is a rapid strictly intralesional injection of triamcinolone at } 40 \mathrm{mg} \text { diluted I:I with lidocaine, } \\
\text { or betamethasone or methylprednisolone (the latter not diluted). } \\
\text { Combination of triamcinolone with 5-FU and lidocaine reduces risk of skin atrophy. } \\
\text { Possible use of hyaluronidase in combination with triamcinolone at early stage. }\end{array}$ \\
\hline
\end{tabular}

Notes: *Focused on HAs (hyaluronic acids); ${ }^{\dagger}$ In case of HA-induced granuloma, hyaluronidase is recommended; ${ }^{\ddagger}$ With algorithm. For more detailed information, refer to the publications.

Abbreviations: IL, Intralesional; 5-FU, 5-Fluoruracil.

is a last resort, because of the difficulty of removing the granuloma completely, given its spreading contour, and the risk of infection and scars. The treatments of granuloma after injection with another polymer-based collagen stimulator (Polylactic acid - PLLA), often reported before the proposed dilution protocol, are detailed in the American and European recommendations, ${ }^{113,118}$ and follow similar modalities. Intralesional corticosteroid injection was reported to be less effective in nodules caused by the calcium hydroxyapatite-based collagen stimulator. ${ }^{112}$

Although the PCL-filler is not known to be associated with granuloma (incidence rate of $0.002 \%$ ), it is important to provide information on the treatment recommended by a group of experts, that can be used by physicians to handle this complication, given the seriousness for their patients. The treatment described in detail (Figure 4) starts by systemic treatment with prednisone $1 \mathrm{mg} / \mathrm{kg}$ per day for 1 week with intralesional injection of microinjection of a solution of corticosteroid, methylprednisolone or triamcinolone $20 \mathrm{mg} / \mathrm{mL}$ final concentration; methotrexate or 5-FU can be added. This can be a long-term treatment of several months, which can be stopped and reinitiated according to progression. The physician should closely follow the effect of the complication treatment.

A new technique for nodules/granuloma treatment was developed in recent years as an option before surgery: the intralesional laser treatment (ILT) to help remove the product; the area is treated by local introduction of a micro-optic laser fiber several times at different places in the target area. ${ }^{119-121}$ Several hundred cases involving different types of fillers, especially permanent dermal fillers were treated by ILT. ${ }^{119,120}$ This technique applied to the PCL filler showed benefit in the very few treated cases given the extremely low AE incidence. ${ }^{121}$ The physicochemical properties of the PCL polymer, with a low melting point, should make it particularly sensitive to this technique. ILT appears to be a promising option should such complication occurs with the PCL filler.

The role of biofilms in granuloma formation has been evoked by some experts, ${ }^{122}$ and is debated among physicians. Anyway, infection has to be ruled out, or else antibiotherapy should be initiated. Antibiotics has been recommended as part of the treatment..$^{99,123,124}$ also refer to Table 2. 
Finally, the most severe immediate-onset reactions of dermal fillers are vascular impairment events, reported at an extremely low rate for dermal fillers but that are devastating. Physicians have to be particularly aware of this complication and cautious about the area to treat, the volume injected and the speed of injection. Good knowledge of anatomy, and particularly of the danger zones, is needed. ${ }^{106,125}$ Time is short for the physician to intervene; prompt recognition of the problem, particularly appearance of pain, skin discoloration allows treatment to be stopped and complication treatment started immediately; topical nitropaste under occlusive dressing, high dose of hyaluronidase, oral acetylsalicylic acid (aspirin), warm compresses and vigorous massage have been recommended; secondary lines of treatment may involve hyperbaric oxygen therapy and ancillary vasodilating agents such as prostaglandin E1. ${ }^{126-128}$ A metanalysis of vascular complications of facial fillers provides an interesting update. ${ }^{129}$

To conclude, complications caused by dermal fillers are rare and mostly minor and injection-related but physicians have to be aware of the risk and be able to manage and treat adverse events, particularly the severe ones. It is difficult to have access to PMS data of the different fillers, as they are generally not published. If we consider safety data covering several years based on clinical experience, four recent analyses on FDA Manufacturer and User Device Experience databases (MAUDE) reported adverse events after several FDA-approved dermal fillers and collagen stimulators (Radiesse, Sculptra) leading to litigation provide interesting information, even limited, regarding the types of adverse events and the area the most affected, as a mean to evaluate the risk. One covers the period of 2014-2016 ${ }^{130}$ showing swelling and infection the most common, more serious events include vascular compromise, resulting in necrosis and blindness; the second from 2013 to $2017^{131}$ evidenced swelling, nodules and pain as the most frequent. The most frequent locations were the cheek, lips and NLFs. Forehead and dorsal nasal injections are the area leading the most to vascular complications. resulting in necrosis and visual symptoms. The other ${ }^{132}$ covers the period 1993-2014, with common AEs lumps, infection, allergic reaction, ischemia and swelling; rare events include autoimmune reactions, visual disturbances and swelling. A 10-year (2007-2017) retrospective study assessed the various complications with esthetic products as well. The objective is to allow physicians to be aware of the possible AEs and to develop treatment strategies. ${ }^{133}$ Treatment options and recommendations for dermal fillers complications have been published by many experts, as presented previously.

PCL filler safety has been particularly studied showing a good safety profile. Treatment of complications is proposed as guidance for physicians should they face such a situation, they could adapt them according to the patients' condition and response to treatment (Figure 4).

\section{Discussion and Conclusion}

Since their discovery, polymers have occupied a very important place, given their numerous applications, including biomedical use in tissue engineering. Polycaprolactone, a well-known polymer, has several specific and interesting properties: it is biocompatible, slowly biodegradable and bioresorbable. Thanks to the development of tissue engineering and, more recently, applications of 3D printing in the biomedical field, interest in PCL has increased, and scientists and physicians are working on futuristic biomedical applications, some already applied in severe pathological conditions. A recent new area of PCL application concerns esthetics, a field of growing interest, with the recent introduction of the PCL collagen stimulator for facial rejuvenation. It exerts a dual effect, an immediate volumizing effect by the CMC gel and a sustained effect thanks to collagen production and unique scaffold formation with the microspheres. The longterm efficacy and duration of action as well as the safety of the PCL-filler is confirmed in clinical studies and by daily clinical practice worldwide over 10 years. Volume restoration, reshaping and rejuvenating effects provide long-lasting natural results and skin quality improvement. The rate of adverse events is low and no unexpected adverse events have been reported. Importantly there are various means of treating rare adverse events should they appear and experts' guidelines are provided; physicians have to be made aware of those recommended treatments in the course of training, and to be prepared to use them in their practice. Research is ongoing to optimize adverse-event treatment, taking advantage of the physicochemical properties related to PCL. Intralesional Laser therapy (ILT) among others is an interesting option that is being further worked out. Fundamental investigations of its mechanism of action should provide new insight into its effects, in relation to collagen stimulation and 3D-scaffold formation. The essential place of mechanobiology is further considered, which will shed light on various aspects of the PCL-filler clinical effects. It is also interesting to continue elucidating the mechanism underlying the improvement in skin quality reported by many physicians as well as in clinical studies. Ongoing research on crosstalk 
between fibroblasts and keratinocytes and interaction with adipocytes should bring further understanding of this effect.

Differences exist between the collagen stimulators on their efficacy, duration of action and safety but no standardized clinical study has been conducted so far to compare them. As an additional perspective, large clinical trials are expected to investigate the effect of the PCL-filler in other esthetic applications, including combination treatment and body applications, both being the current trends in esthetics, to optimize treatment and enable global rejuvenation.

This overall scientific and medical information contributes to general knowledge of esthetic procedures and optimal management. Finally, the present review illustrates the interest in the well-known polymer, polycaprolactone, as a material in tissue engineering, besides its key role, in a new expanding domain in esthetics, by the use of the PCLbased rejuvenating filler, which opens up new perspectives.

\section{Acknowledgment}

The authors want to thank Abelia Science for their help in writing the manuscript.

\section{Author Contributions}

All authors contributed to data analysis, drafting or revising the article, gave final approval of the version to be published, and agree to be accountable for all aspects of the work.

\section{Disclosure}

The authors are consultants for Sinclair Pharma. Mrs MarieOdile Christen reports personal fees from Sinclair Pharma, outside the submitted work. Dr Franco Vercesi is the International Key Opinion Leader for Sinclair Pharma. The authors report no other conflicts of interest in this work.

\section{References}

1. American Society of Plastic Surgeons (ASPS). Plastic surgery statistics report; 2018. Available from: https://www.plasticsurgery.org/docu ments/News/Statistics/2018/plastic-surgery-statistics-report-2018.pdf. Accessed August 28, 2019.

2. US Food \& Drug Administration (FDA). Dermal fillers (soft tissue fillers). Available from: https://www.fda.gov/medical-devices/cosmetic-devices /dermal-fillers-soft-tissue-fillers. Accessed August 28, 2019.

3. Agence Nationale de Sécurité du Médicament et des Produits de santé (ANSM). Topical report. Injectable products to fill wrinkles; July 2012. Available from: https://ansm.sante.fr/var/ansm_site/storage/origi nal/application/0c98df139d4879353a001e5420660ae1.pdf. Accessed August 28, 2019.

4. Goldberg D, Guana A, Volk A, Daro-Kaftan E. Single-arm study for the characterization of human tissue response to injectable poly-L-lactic acid. Dermatol Surg. 2013;39(6):915-922. doi:10.1111/ dsu. 12164
5. Gritzalas K. Preliminary results in using a new dermal filler based on poly-caprolactone. Eur J Aesth Med Dermatol. 2011;1 (1):22-26.

6. Gunatillake PA, Adhikari R. Biodegradable synthetic polymers for tissue engineering. Eur Cell Mater. 2003;5:1-16. Discussion 16. doi:10.22203/eCM.v005a 01

7. Woodruff MA, Hutmacher DW. The return of a forgotten polymer. Polycaprolactone in the 21st century. Prog Polym Sci. 2010;35:1217-1256. doi:10.1016/j.progpolymsci.2010.04.002

8. Labet M, Thielemans W. Synthesis of polycaprolactone: a review. Chem Soc Rev. 2009;38(12):3484-3504. doi:10.1039/b820162p

9. Guarino V, Gentile G, Sorrentino L, Ambrosio L. Polycaprolactone: synthesis, properties, and applications. Encycl Polym Sci Technol. 2017;1-36. doi:10.1002/0471440264.pst658

10. Sinha VR, Bansal K, Kaushik R, Kumria R, Trehan A. Poly-ecaprolactone microspheres and nanospheres: an overview. Int J Pharma. 2004;278:1-23. doi:10.1016/j.ijpharm.2004.01.044

11. Azimi B, Nourpanah P, Rabiee M, Arbab S. Poly ( $\varepsilon$-caprolactone) fiber: an overview. J Eng Fiber Fabr. 2014;9:74-90.

12. Abedalwafa M, Wang F, Lu Wang L, Li C. Biodegradable poly-epsilon-caprolactone (PCL) for tissue engineering applications: a review. Rev Adv Mater Sci. 2013;34:123-140.

13. Mohamed RM, Yusoh K. A review on the recent research of polycaprolactone (PCL). Adv Mater Res. 2016;1134:249-255. doi:10.4028/www.scientific.net/AMR.1134.249

14. Woodward SC, Brewer PS, Moatamed F, Schindler A, Pitt CG. The intracellular degradation of poly(epsilon-caprolactone). J Biomed Mater Res. 1985;19(4):437-444. doi:10.1002/jbm.820190408

15. Pitt CG, Gratzl MM, Kimmel GL, Surles J, Schindler A. Aliphatic polyesters II. The degradation of poly (DL-lactide), poly (epsilon-caprolactone), and their copolymers in vivo. Biomaterials. 1981;2(4):215-220. doi:10.1016/0142-9612(81)90060-0

16. Sun H, Mei L, Song C, Cui X, Wang P. The in vivo degradation, absorption, and excretion of PCL-based implant. Biomaterials. 2006;27(9):1735-1740. doi:10.1016/j.biomaterials.2005.09.019

17. Ma G, Song C, Sun H, Yang J, Leng X. A biodegradable levonorgestrel-releasing implant made of PCL/F68 compound as tested in rats and dogs. Contraception. 2006;74(2):141-147. doi:10.1016/j. contraception.2006.02.013

18. Heimowska A, Morawska M, Bocho-Janiszewska A. Biodegradation of poly( $\varepsilon$-caprolactone) in natural water environments. Pol J Chem Tech. 2017;19(1):120-126. doi:10.1515/pjct-2017-0017

19. Malikmammadov E, Tanir TE, Kiziltay A, Hasirci V, Hasirci N. PCL and PCL-based materials in biomedical applications. J Biomater Sci Polym Ed. 2017;1-31. doi:10.1080/09205063.2017.1394711

20. Mondal D, Griffith M, Venkatraman SS. Polycaprolactone-based biomaterials for tissue engineering and drug delivery: current scenario and challenges. Int J Polym Mater Polym Biomater. 2016;65 (5):255-265. doi:10.1080/00914037.2015.1103241

21. Dash TK, Konkimalla VB. Poly-e-caprolactone based formulations for drug delivery and tissue engineering: a review. $J$ Control Release. 2012;158(1):15-33. doi:10.1016/j.jconrel.2011.09.064

22. Ulery BD, Nair LS, Laurencin CT. Biomedical applications of biodegradable polymers. $J$ Polym Sci B Polym Phys. 2011;49:832-864.

23. Bezwada RS, Jamiolkowski DD, Lee IY, et al. Monocryl suture, a new ultra-pliable absorbable monofilament suture. Biomaterials. 1995;16(15):1141-1148. doi:10.1016/0142-9612(95)93577-Z

24. Das GS, Rao GH, Wilson RT, Chandy T. Colchicine encapsulation with poly (ethylene glycol) - coated poly (lactic acid) poly (epsilon-caprolactone) microspheres controlled release studies. Drug Deliv. 2000;7:129-138. doi:10.1080/10717540050120160

25. Dordunoo SK, Jackson JK, Arsenault LA, Oktaba AMC, Hunter WL, Burt HM. Taxol encapsulation in poly (epsilon-caprolactone). Cancer Chemother Pharmacol. 1995;36(4):279-282. doi:10.1007/BF0068 9043 
26. Chang R, Price JC, Whitworth CW. Dissolution characteristics of poly-caprolactone-polylactide microspheres of chlorpromazine. Drug Dev Ind Pharm. 1986;12:2355-2380. doi:10.3109/03639 048609063187

27. Carreras N, Acuña V, Martí M, Lis MJ. Drug release system of ibuprofen in PCL-based microspheres. Colloid Polym Sci. 2013;291(1):157-165. doi:10.1007/s00396-012-2768-x

28. Giunchedi P, Conti B, Maggi L, Conti U. Cellulose acetate butyrate and polycaprolactone for ketoprofen spray-dried microspheres preparation. J Microencapsul. 1994;11:381-393. doi:10.1002/ biot.201600734

29. Perez MH, Zinutti CC, Lamprecht A, et al. The preparation and evaluation of poly(e-caprolactone) microparticles containing both a lipophilic and a hydrophilic drug. $J$ Control Release. 2000;65:429-438. doi:10.1016/S0168-3659(99)00253-9

30. Middleton JC, Tipton AJ. Synthetic biodegradable polymers as orthopedic devices. Biomaterials. 2000;21:2335-2346. doi:10.1016/ S0142-9612(00)00101-0

31. Mogosanu GD, Grumezescu AM. Natural and synthetic polymers for wounds and burns dressing. Int J Pharm. 2014;463:127-136. doi:10.1016/j.ijpharm.2013.12.015

32. Hernandez I, Kumar A, Joddar B. A bioactive hydrogel and 3D printed polycaprolactone system for bone tissue engineering. Gels. 2017;3:pii26. doi:10.3390/gels3030026

33. Avolio E, Caputo M, Madeddu P. Stem cell therapy and tissue engineering for correction of congenital heart disease. Front Cell Dev Biol. 2015;3:39. doi:10.3389/fcell.2015.00039

34. He Y, Kilsby S, Tuck C, et al. Processing biodegradable polycaprolactone through 3D printing. Sci Transl Med. 2015;7 (285):285ra64. doi:10.1126/scitranslmed.aad3106

35. Vijayavenkataraman S, Fuh JYH, Lu WF. 3D printing and 3D bioprinting in pediatrics. Bioengineering. 2017;4(3):63.

36. Do AV, Khorsand B, Geary SM, Salem AK. 3D printing of scaffolds for tissue regeneration applications. Adv Healthc Mater. 2015;4(12):1742-1762. doi:10.1002/adhm.201500168

37. Dawood A, Marti Marti B, Sauret-Jackson V, Darwood A. 3D printing in dentistry. $B r$ Dent $J . \quad$ 2015;219(11):521-529. doi:10.1038/sj.bdj.2015.914

38. Huang Y, Zhang XF, Gao G, Yonezawa T, Cui X. 3D bioprinting and the current applications in tissue engineering. Biotechnol $J$. 2017;12:8. doi:10.1002/biot.201600734

39. Li C, Cheung TF, Fan VC, Sin KM, Wong CW, Leung GK. Applications of three-dimensional printing in surgery. Surg Innov. 2017;24(1):82-88. doi:10.1177/1553350616681889

40. Zopf DA, Flanagan CL, Wheeler M, Scott J, Hollister SJ, Green GE. Treatment of severe porcine tracheomalacia with a 3-Dimensionally printed, bioresorbable, external airway splint. JAMA Otolaryngol. 2014;140:66-71. doi:10.1001/jamaoto.2013.5644

41. Zopf DA, Hollister SJ, Nelson ME, Ohye RG, Green GE. Bioresorbable airway splint created with a three-dimensional printer. New Engl J Med. 2013;368:2043-2045. doi:10.1056/ NEJMc1206319

42. Morrison RJ, Hollister SJ, Niedner MF, et al. Mitigation of tracheobronchomalacia with 3D-printed personalized medical devices in pediatric patients. Sci Transl Med. 2015;7(285):285ra64. doi:10.1126/scitranslmed.3010825

43. Huang L, Wang L, He J, et al. Tracheal suspension by using 3-dimensional printed personalized scaffold in a patient with tracheomalacia. $J$ Thorac Dis. 2016;8:3323-3328. doi:10.21037/jtd

44. Gao M, Zhang H, Dong W, et al. Tissue-engineered trachea from a 3D-printed scaffold enhances whole-segment tracheal repair. Sci Rep. 2017;7:5246. doi:10.1038/s41598-017-05518-3

45. Chan DS, Fnais N, Ibrahim I, Daniel S, Manoukian J. Exploring polycaprolactone in tracheal surgery: a scoping review of in-vivo studies. Int J Pediatr Otorhinolaryngol. 2019;123:38-42. doi:10.1016/ j.ijporl.2019.04.039
46. Kankala RK, Zhu K, Li J, Wang CS, Wang SB, Chen AZ. Fabrication of arbitrary 3D components in cardiac surgery: from macro-, micro- to nanoscale. Biofabrication. 2017;9(3):032002. doi:10.1088/1758-5090/aa8113

47. Hendow EK, Guhmann P, Wright B, et al. Biomaterials for hollow organ tissue engineering. Fibrogenesis Tissue Repair. 2016;9:3. doi:10.1186/s13069-016-0040-6

48. Rasperini G, Pilipchuk SP, Flanagan CL, et al. 3D-printed bioresorbable scaffold for periodontal repair. J Dent Res. 2015;94(9 Suppl 2):S153-S157.

49. Sun J, Vijayavenkataraman S, Liu H. An overview of scaffold design and fabrication technology for engineered knee meniscus. Materials (Basel). 2017;10(1):pii:E29. doi:10.3390/ ma10010029

50. Szojkaa A, Lalha K, Andrewsa SHJ, Jomhaa NM, Osswalda M. Biomimetic 3D printed scaffolds for meniscus tissue engineering. Bioprinting. 2017;8:1-7. doi:10.1016/j.bprint.2017.08.001

51. Zhang ZZ, Wang SJ, Zhang JY, et al. 3D-printed Poly( $\varepsilon-$ caprolactone) scaffold augmented with mesenchymal stem cells for total meniscal substitution: a 12- and 24-week animal study in a rabbit model. Am J Sports Med. 2017;45(7):1497-1511. doi:10.1177/0363546517691513

52. Varani J, Dame MK, Rittie L, et al. Decreased collagen production in chronologically aged skin - roles of age-dependent alteration in fibroblast function and defective mechanical stimulation. $\mathrm{Am}$ J Pathol. 2006;168:1861-1868. doi:10.2353/ajpath.2006.051302

53. Uitto J. The role of elastin and collagen in cutaneous aging: intrinsic aging versus photoexposure. J Drugs Dermatol. 2008;7(2 Suppl):S12-S16.

54. Waller JM, Maibach HI. Age and skin structure and function, a quantitative approach (II): protein, glycosaminoglycan, water, and lipid content and structure. Skin Res Technol. 2006;12:145-154. doi:10.1111/srt.2006.12.issue-3

55. Rittié L, Fisher GJ. Natural and sun-induced aging of human skin. Cold Spring Harb Perspect Med. 2015;5(1):a015370. doi:10.1101/ cshperspect.a015370

56. Cole MA, Quan T, Voorhees JJ, Fisher GJ. Extracellular matrix regulation of fibroblast function: redefining our perspective on skin aging. J Cell Commun Signal. 2018;12(1):35-43. doi:10.1007/ s12079-018-0459-1

57. Christen MO. Tissular induction and the role of collagens: from development to senescence. $J$ Med Esth Et Chir Derm. 2016; XXXXIII(169): 19-28.

58. Birch HL. Extracellular matrix and ageing. Subcell Biochem. 2018;90:169-190.

59. Shin JW, Soon-Hyo Kwon SH, Choi JY, et al. Review: molecular mechanisms of dermal aging and antiaging approaches. Int $\mathrm{J} \mathrm{Mol}$ Sci. 2019;20:2126. doi:10.3390/ijms2009212652

60. Nicolau PJ, Marijnissen-Hofsté JM. Neocollagenesis after injection of a polycaprolactone based dermal filler in a rabbit. EJAMeD. 2013;3(1):19-26.

61. Kim JA, Van Abel D. Neocollagenesis in human tissue injected with a polycaprolactone-based dermal filler. $J$ Cosmet Laser Ther. 2015;17(2):99-101. doi:10.3109/14764172.2014.968586

62. Kim J. Changes in dermal thickness in biopsy study of histologic findings after a single injection of polycaprolactone-based filler into the dermis. Aesthet Surg J. 2019;39(12):NP484-NP494. doi:10.10 93/asj/sjz050

63. Reinke JM. Wound repair and regeneration. Eur Surg Res. 2012;49:35-43. doi:10.1159/000339613

64. Rittié L. Cellular mechanisms of skin repair in humans and other mammals. J Cell Commun Signal. 2016;10(2):103-120. doi:10.10 07/s12079-016-0330-1

65. Ratner BD. A pore way to heal and regenerate: 21 st century thinking on biocompatibility. Regen Biomater. 2016;3:107-110. doi:10. 1093/rb/rbw006 
66. Sheikh Z, Brooks PJ, Barzilay O, Fine N, Glogauer M. Macrophages, foreign body giant cells and their response to implantable biomaterials. Materials. 2015;8:5671-5701. doi:10.3390/ma8095269

67. Laeschke K. Biocompatibility of microparticles into soft tissue fillers. Semin Cutan Med Surg. 2004;23(4):214-217. doi:10.1016/ j.sder.2004.09.005

68. Matlaga BF, Yasenchak LP, Salthouse TN. Tissue response to implanted polymers: the significance of sample shape. $J$ Biomed Mater Res. 1976;10(3):391-397. doi:10.1002/(ISSN)1097-4636

69. Wang F, Garza LA, Kang S, et al. In vivo stimulation of de novo collagen production caused by cross-linked hyaluronic acid dermal filler injections in photodamaged human skin. Arch Dermatol. 2007;143(2):155-163. doi:10.1001/archderm.143.2.155

70. Fisher GJ, Varani J, Voorhees JJ. Looking older: fibroblast collapse and therapeutic implications. Arch Dermatol. 2008;144 (5):666-672. doi:10.1001/archderm.144.5.666

71. Bachir A, Horwitz AR, Nelson WJ, Bianchini JM. Actin-based adhesion modules mediate cell interactions with the extracellular matrix and neighboring cells. Cold Spring Harb Perspect Biol. 2017;9(7):Pii.a023234. doi:10.1101/cshperspect.a023234

72. Ohashi K, Fujiwara S, Mizuno K. Roles of the cytoskeleton, cell adhesion and rho signalling in mechanosensing and mechanotransduction. J Biochem. 2017;161(3):245-254. doi:10.1093/jb/mvw082

73. Ingber DE, Wang N, Stamenovic D. Tensegrity, cellular biophysics, and the mechanics of living systems. Rep Prog Phys. 2014;77 (4):046603. doi:10.1088/0034-4885/77/4/046603

74. Phillip JM, Aifuwa I, Walston J, Wirtz D. The mechanobiology of aging. Annu Rev Biomed Eng. 2015;17:113-141. doi:10.1146/ annurev-bioeng-071114-040829

75. Moers-Carpi MM, Sherwood S. Polycaprolactone for the correction of nasolabial folds: a 24-month, prospective, randomized, controlled clinical trial. Dermatol Surg. 2013;39(3 Pt 1):457-463. doi:10.1111/dsu. 12054

76. Galadari H, van Abel D, Al Nuami K, Al Faresi F, Galadari I. A randomized, prospective, blinded, split-face, single-center study comparing polycaprolactone to hyaluronic acid for treatment of nasolabial folds. $J$ Cosmet Dermatol. 2015;14(1):27-32. doi:10.1111/jocd.2015.14.issue-1

77. Christen MO, Meadows J Ellansé: science and safety update. Communication at the World Expert meeting (WEM) 2018; October 10; 2018; Barcelona

78. Lin SL. Polycaprolactone facial volume restoration of a 46-year-old Asian women: a case report. J Cosmet Dermatol. 2018;17:328-332. doi:10.1111/jocd.12482

79. Bae B, Lee G, Oh S, Hong K. Safety and long-term efficacy of forehead contouring with a polycaprolactone-based dermal filler. Dermatol Surg. 2016;42(11):1256-1260. doi:10.1097/DSS.0000000000000913

80. Figueiredo VM. A five-patient prospective pilot study of a polycaprolactone based dermal filler for hand rejuvenation. J Cosmet Dermatol. 2013;12(1):73-77. doi:10.1111/jocd.2013.12.issue-1

81. de Melo F, Nicolau P, Piovano L, et al. Recommendations for volume augmentation and rejuvenation of the face and hands with the new generation polycaprolactone-based collagen stimulator (Ellansé ${ }^{\circledR}$ ). Clin Cosmet Investig Dermatol. 2017;10:431-440. doi:10.2147/CCID.S145195

82. Delmar H Ellansé: a European multicentre long-term safety and efficacy study. Communication at IMCAS 2019; February 1; 2019; Paris

83. Sheikh A, Smith J Ellanse ${ }^{\circledR}$ Safety: PMS. Sinclair Internal data 2018.

84. Moon SY, Eun DH, Park JH, et al. Foreign body reaction three years after injection with polycaprolactone (Ellansé). Eur J Dermatol. 2017;27:549-551. doi:10.1684/ejd.2017.3089

85. Skrzypek E, Gornicka B, Skrzypek DM, Krzysztof MR. Granuloma as a complication of polycaprolactone-based dermal filler injection: ultrasound and histopathology studies. $J$ Cosmet Laser Ther. 2018;21(6):1-4.
86. Or L, Eviatar JA, Massry GG, Bernardini FP, Hartstein ME. Xanthelasma-like reaction to filler injection. Ophthalmic Plast Reconstr Surg. 2017;33(4):244-247. doi:10.1097/IOP.00000000000 00722

87. Lin S Complications of a PCl-based dermal filler: causes, management, prevention and incidence rate. Communication at IMCAS Americas; August 2; 2019; Cartagena de Indias

88. Urdiales-Gálvez F, Delgado NE, Figueiredo V, et al. Preventing the complications associated with the use of dermal fillers in facial aesthetic procedures: an expert group consensus report. Aesthetic Plast Surg. 2017;41(3):667-777. doi:10.1007/s00266-017-0798-y

89. Ozturk CN, Li Y, Tung R, Parker L, Piliang MP, Zins JE. Complications following injection of soft-tissue fillers. Aesthet Surg J. 2013;33(6):862-877. doi:10.1177/1090820X13493638

90. Funt D, Pavicic T. Dermal fillers in aesthetics: an overview of adverse events and treatment approaches. Clin Cosmet Investig Dermatol. 2013;6:295-316. doi:10.2147/CCID.S50546

91. Kim JH, Ahn DK, Jeong HS, Suh IS. Treatment algorithm of complications after filler injection: based on wound healing process. J Korean Med Sci. 2014;29(Suppl 3):S176-S182. doi:10.3346/jkms.2014.29.S3.S176

92. De Boulle K, Heydenrych I. Patients influencing dermal filler complications: prevention, assessment, and treatment. Clin Cosmet Investig Dermatol. 2015;8:205-214. doi:10.2147/CCID.S80446

93. Funt D, Pavicic T. Dermal fillers in aesthetics: an overview of adverse events and treatment approaches. Plast Surg Nurs. 2015;35(1):13-32. doi:10.1097/PSN.0000000000000087

94. Rzany B, DeLorenzi C. Understanding, avoiding, and managing severe filler complications. Plast Reconstr Surg. 2015;136(5 Suppl):S196-S203. doi:10.1097/PRS.0000000000001760

95. Woodward J, Khan T, Martin J. Facial filler complications. Facial Plast Surg Clin North Am. 2015;23(4):447-458. doi:10.1016/j. fsc.2015.07.006

96. Abduljabbar MH, Basendwh MA. Complications of hyaluronic acid fillers and their managements. J Dermatol Dermatol Surg. 2016;20:100-106. doi:10.1016/j.jdds.2016.01.001

97. Fitzgerald R, Bertucci V, Sykes JM, Duplechain JK. Adverse reactions to injectable fillers. Facial Plast Surg. 2016;32(5):532-555. doi:10.1055/s-0036-1592340

98. King M, Bassett S, Davies E, King S. Management of delayed onset nodules. J Clin Aesthet Dermatol. 2016;9(11):1-5.

99. Signorini M, Liew S, Sundaram H, et al.; for Global Aesthetics Consensus Group. Global aesthetics consensus: avoidance and management of complications from hyaluronic acid fillers-evidence- and opinion-based review and consensus recommendations. Plast Reconstr Surg. 2016;137(6):961e-971e. doi:10.1097/PRS.0000000000002184.

100. Vanaman M, Fabi SG, Carruthers J. Complications in the cosmetic dermatology patient: a review and our experience (part I). Dermatol Surg. 2016;42:1-11. doi:10.1097/DSS.0000000000000569

101. Chiang YZ, Pierone G, Al-Niaimi F. Dermal fillers: pathophysiology, prevention and treatment of complications. J Eur Acad Dermatol Venereol. 2017;31(3):405-413. doi:10.1111/jdv.2017.31.issue-3

102. Philipp-Dormston WG, Bergfeld D, Sommer BM, et al. Consensus statement on prevention and management of adverse effects following rejuvenation procedures with hyaluronic acid based fillers. $J$ Eur Acad Dermatol Venereol. 2017;31(7):1088-1095. doi:10.1111/jdv.2017.31.issue-7

103. Graivier MH, Bass LM, Lorenc ZP, Fitzgerald R, Goldberg DJ, Lemperle G. Differentiating nonpermanent injectable fillers: prevention and treatment of filler complications. Aesthet Surg J. 2018;3:529-540.

104. Heydenrych I, Kapoor KM, De Boulle K, et al. A 10-point plan for avoiding hyaluronic acid dermal filler-related complications during facial aesthetic procedures and algorithms for management. Clin Cosmet Investig Dermatol. 2018;11:603-611. doi:10.2147/CCID. S180904 
105. Urdiales-Gálvez F, Delgado NE, Figueiredo V, et al. Treatment of soft tissue filler complications: expert consensus recommendations. Aesthetic Plast Surg. 2018;42(2):498-510. doi:10.1007/s00266017-1063-0

106. Scheuer JF, Sieber DA, Pezeshk RA, Gassman AA, Campbell CF, Rohrich RJ. Facial danger zones: techniques to maximize safety during soft-tissue filler injections. Plast Reconstr Surg. 2017;139:1103-1108. doi:10.1097/PRS.0000000000003309

107. Wortsman X, Quezada N. Ultrasound morphology of polycaprolactone filler. J Ultrasound Med. 2017;36(12):2611-2615. doi:10.1002/ jum.v36.12

108. Wortsman X. Identification and complications of cosmetic fillers: sonography first. J Ultrasound Med. 2015;34(7):1163-1172. doi:10.7863/ultra.34.7.1163

109. Seok J, Kim JM, Kwon TR, Kim JH, Li K, Kim BJ. Ultrasonographyguided curettage of poly-DL-lactic acid filler granulomas. J Am Acad Dermatol. 2018;78(1):e5-e6. doi:10.1016/j.jaad.2017.08.026

110. Schelke LW, Decates TS, Velthuis PJ. Ultrasound to improve the safety of hyaluronic acid filler treatments. J Cosmet Dermatol. 2018;17(6):1019-1024. doi:10.1111/jocd.2018.17.issue-6

111. Funt DK. Avoiding malar edema during midface/cheek augmentation with dermal filler. J Clin Aesthet Dermatol. 2011;4(12):32-36.

112. Lemperle G, Duffy DM. Treatment options for dermal filler complications. Aesthet Surg J. 2006;26(3):356-364. doi:10.1016/j. asj.2006.04.002

113. Redaelli A, Rzany B, Eve L, et al. European expert recommendations on the use of injectable poly-L-lactic acid for facial rejuvenation. J Drugs Dermatol. 2014;13(9):1057-1066.

114. Lemperle G, Gauthier-Hazan N, Wolters M, Eisemann-Klein M, Zimmermann U, Duffy DM. Foreign body granulomas after all injectable dermal fillers: part 1. Possible causes. Plast Reconstr Surg. 2009;123(6):1842-1863. doi:10.1097/PRS.0b013e31818236d7

115. Lemperle G, Gauthier-Hazan N. Foreign body granulomas after all injectable dermal fillers: part 2. Treatment options. Plast Reconstr Surg. 2009;123(6):1864-1873117. doi:10.1097/PRS.0b013e31818 $58 \mathrm{f} 4 \mathrm{f}$

116. Alijotas-Reig J, Fernández-Figueras MT, Puig L. Late-onset inflammatory adverse reactions related to soft tissue filler injections. Clin Rev Allergy Immunol. 2013;45(1):97-108. doi:10.1007/s12016012-8348-5

117. Lee JM, Kim YJ. Foreign body granulomas after the use of dermal fillers: pathophysiology, clinical appearance, histologic features, and treatment. Arch Plast Surg. 2015;42:232-239. doi:10.5999/ aps.2015.42.2.232

118. Vleggaar D, Fitzgerald R, Lorenc ZP. Understanding, avoiding, and treating potential adverse events following the use of injectable poly-L-lactic acid for facial and nonfacial volumization. $J$ Drugs Dermatol. 2014;13(4 Suppl):S35-S39.

119. Cassuto D, Marangoni O, De Santis G, Christensen L. Advanced laser techniques for filler-induced complications. Dermatol Surg. 2009;35(Suppl 2):S1689-S1695. doi:10.1111/j.1524-4725.2009. 01348.x
120. Cassuto D, Pignatti M, Pacchioni L, Boscaini G, Spaggiari A, De Santis G. Management of complications caused by permanent fillers in the face: a treatment algorithm. Plast Reconstr Surg. 2016;138(2):215e-227e. doi:10.1097/PRS.0000000000002350

121. Schelke LW, Decates TS, van der Lugt CIM, Pelzer L, de Mey G, Velthuis PJ. Intralesional laser treatment for dermal fillers complications. Plast Reconstr Surg. 2018;141(6):1361-1369. doi:10.1097/PRS.0000000000004428

122. Ibrahim O, Overman J, Arndt KA, Dover JS. Filler nodules: inflammatory or infectious? A review of biofilms and their implications on clinical practice. Dermatol Surg. 2018;44(1):53-60. doi:10.1097/DSS.0000000000001202

123. Wagner RD, Fakhro A, Cox JA, Izaddoost SA. Etiology, prevention, and management of infectious complications of dermal fillers. Semin Plast Surg. 2016;30(2):83-86. doi:10.1055/s-0036-1580734

124. Ferneini EM, Beauvais D, Aronin SL. An overview of infections associated with soft tissue fillers: identification, prevention, and treatment. J Oral Maxillofac Surg. 2017;75:160-166. doi:10.1016/ j.joms.2016.09.004

125. Brennan C. Avoiding the "danger zones" when injecting dermal fillers and volume enhancers. Plast Surg Nurs. 2014;34 (3):108-111. doi:10.1097/PSN.0000000000000053

126. DeLorenzi C. Complications of injectable fillers, part 2: vascular complications. Aesthet Surg J. 2014;34(4):584-600. doi:10.1177/ 1090820X14525035

127. Goodman GJ, Roberts S, Callan P. Experience and management of intravascular injection with facial fillers: results of a multinational survey of experienced injectors. Aesthetic Plast Surg. 2016;40 (4):549-555. doi:10.1007/s00266-016-0658-1

128. Beleznay K, Carruthers JDA, Humphrey S, Carruthers A, Jones D. Update on avoiding and treating blindness from fillers: a recent review of the world literature. Aesthet Surg J. 2019;39(6):662-674. doi:10.1093/asj/sjz053

129. Sito G, Manzoni V, Sommariva R. Vascular complications after facial filler injection: a literature review and meta-analysis. J Clin Aesthet Dermatol. 2019;12(6):E65-E72.

130. Rayess HM, Svider PF, Hanba C, et al. A cross-sectional analysis of adverse events and litigation for injectable fillers. JAMA Facial Plast Surg. 2018;20(3):207-214. doi:10.1001/jamafacial.2017.1888

131. Beauvais D, Ferneini EM. Complications and litigation associated with injectable facial fillers: a cross-sectional study. J Oral Maxillofac Surg. 2019;pii: S0278-2391(19)30946-2. doi:10.1016/ j.joms.2019.08.003

132. Ortiz AE, Ahluwalia J, Song SS, Avram MM. Analysis of U.S food and drug administration data on soft-tissue filler complications. Dermatol Surg. 2019;1. doi:10.1097/DSS.0000000000002208

133. Povolotskiy R, Oleck NC, Hatzis CM, Paskhover B. Adverse events associated with aesthetic dermal fillers: a 10-year retrospective study of FDA. Am J Cosmet Surg. 2018;35:143-151. doi: $10.1177 / 0748806818757123$
Clinical, Cosmetic and Investigational Dermatology is an international, peer-reviewed, open access, online journal that focuses on the latest clinical and experimental research in all aspects of skin disease and cosmetic interventions. This journal is indexed on CAS.
The manuscript management system is completely online and includes a very quick and fair peer-review system, which is all easy to use. Visit http://www.dovepress.com/testimonials.php to read real quotes from published authors. 